\title{
Interference of nail polish on the peripheral oxygen saturation in patients with lung problems during exercise ${ }^{1}$
}

\author{
Walkiria Shimoya-Bittencourt ${ }^{2}$ \\ Carlos Alberto de Castro Pereira ${ }^{3}$ \\ Solange Diccini ${ }^{4}$ \\ Ana Rita de Cássia Bettencourt ${ }^{5}$
}

\begin{abstract}
Aim: To assess the interference of nail polish on the reading of peripheral oxygen saturation in patients with chronic obstructive pulmonary disease on the step exercise. Methods: In this study, there was the inclusion of patients with chronic obstructive pulmonary disease, current non-smokers, of both sexes. Four different colours of nail polish were used in the present study (base, light pink, red and brown), randomly distributed among the fingers of the right hand, with the corresponding fingers on the opposite hand being controls. Saturation was measured at rest, with and without the polish, and also during the 4th, 5th and 6th minutes of the exercise programme. Results: The experimental universe included 42 patients with ages of $62.9 \pm 8.7$ years. In the exercise considered, the red colour reduced it in the fourth minute of the exercise $(p=0.047)$. In contrast, the brown colour reduced saturation at rest and also during the course of exercise $(p=0.01)$. Conclusion: In patients with chronic obstructive pulmonary disease, the red and brown colours interfered with the reading of the peripheral oxygen saturation during exercise. This study is registered at the Brazilian Register of Clinical Trials (Registro Brasileiro de Ensaios Clínicos) under No. RBR-9vc722.
\end{abstract}

Descriptors: Pulse Oximetry; Chronic Obstructive Pulmonary Disease; Exercise.

\footnotetext{
1 Paper extracted from Doctoral Dissertation "Interferência do esmalte de unha na leitura da saturação periférica de oxigênio em DPOC no repouso e no exercício", presenteda to Escola Paulista de Enfermagem, Universidade Federal de São Paulo, Brazil.

2 Doctoral Student, Escola Paulista de Enfermagem, Universidade Federal de São Paulo, Brazil.

${ }^{3}$ Physician, PhD, Universidade Federal de São Paulo, Brazil.

${ }^{4}$ PhD, Associate Professor, Escola Paulista de Enfermagem, Universidade Federal de São Paulo, Brazil.

${ }^{5}$ PhD, Adjunct Professor, Escola Paulista de Enfermagem, Universidade Federal de São Paulo, Brasil.
} 


\section{Interferência do esmalte de unha na saturação periférica de oxigênio em pacientes pneumopatas no exercício}

Objetivo: avaliar a interferência do esmalte de unha na leitura da saturação periférica de oxigênio em pacientes com doença pulmonar obstrutiva crônica, no exercício do degrau. Métodos: foram incluídos pacientes com doença pulmonar obstrutiva crônica estável, não fumantes atuais, de ambos os sexos. Utilizaram-se quatro cores de esmalte (base, rosa claro, vermelho e marrom), distribuídas aleatoriamente entre os dedos da mão direita, tendo os dedos contralaterais como controle. A saturação foi medida em repouso com e sem esmalte e durante $040,5^{\circ}$ e $6^{\circ}$ minutos do exercício. Resultados: foram incluídos 42 pacientes com idade de $62,9 \pm 8,7$ anos. No exercício, a cor vermelha diminuiu a mesma no quarto minuto de exercício $(p=0,047)$. A cor marrom reduziu a saturação no repouso e durante o exercício $(p=0,01)$. Conclusão: em pacientes com doença pulmonar obstrutiva crônica, as cores marrom e vermelha interferem na leitura da saturação periférica de oxigênio no exercício. Este estudo está registrado no Registro Brasileiro de Ensaios Clínicos, sob número de registro: RBR-9vc722.

Descritores: Oximetria de Pulso; Doença Pulmonar Obstrutiva Crônica; Exercício.

\section{La interferencia del esmalte de uñas en la saturación periférica de oxígeno en pacientes con pneumopatía en el ejercicio}

Objetivo: Evaluar la interferencia del esmalte de uñas en la lectura de la saturación periférica de oxígeno en pacientes con enfermedad pulmonar obstructiva crónica en el ejercicio de la etapa. Métodos: Fueron incluidos pacientes con enfermedad pulmonar obstructiva crónica estable, no fumadores actuales, de ambos los sexos. Fueron utilizadas cuatro colores de esmalte (base, rosa claro, rojo y marrón) distribuidas aleatoriamente entre los dedos de la mano derecha teniendo los dedos contralaterales como control. La saturación fue medida en reposo con y sin esmalte y durante el $4^{\circ}, 5^{\circ}$ y $6^{\circ}$ minutos del ejercicio. Resultados: Fueron

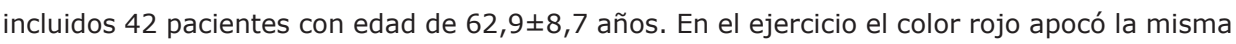
en el cuarto minuto de ejercicio $(p=0,047)$. El color marrón redujo la saturación en el reposo y durante el ejercicio $(p=0,01)$. Conclusión: En pacientes con enfermedad pulmonar obstructiva crónica los colores marrón y rojo interfieren en la lectura de la saturación periférica de oxígeno en el ejercicio. Este estudio está registrado en el Registro Brasileño de Ensayos Clínicos bajo el número de registro: RBR-9vc722.

Descriptores: Oximetría; Enfermedad Pulmonar Obstructiva Crónica; Ejercicio.

\section{Introduction}

Pulse oximetry is a significant advance in noninvasive monitoring, as it not only has low cost, but is also quick and does not need any specialised personnel. It is widely in hospitalisation units, outpatient units, laboratories of pulmonary function, ready service units, Intensive Care therapy, home care and surgical theatres, seeking the early detection of hypoxaemia in different situations ${ }^{(1-3)}$.

Several factors can limit the accuracy of pulse oximetry readings, including the following: states of shock with poor tissue perfusion; oxygen saturation values below $70 \%$; skin pigmentation; certain lighting systems such as surgical lamps, fluorescent lighting and fibroscopic instruments; movement of the sensor; sensor not compatible with the equipment and lack of calibration; high levels of carboxyhaemoglobin, metahaemoglobin and bilirubin (4-9)

The effect of using nail polish on the $\mathrm{SpO}_{2}$ readings is contradictory, as some studies have reported significant reductions(10-12), while others have not observed any changes or have seen changes related to some specific colours $^{(13-20)}$.

Clinical, surgical and emergency scenarios have the routine of removing nail polish. This removal means a need to have the necessary apparatus, as also to guard and/or store the gadgets and also have the consent of 
the patient to remove the nail polish. Thus, time and resources may be saved, and also there is avoidance of a confrontation with patients who refuse to remove their polish.

In addition, in clinical practice it has been observed that the removal of the nail polish is not always due to emergency or urgency situations of the transfer of the patient from the outpatient department to the surgical centre or outpatient surgeries, to where the patient is often admitted hours before the surgical procedure ${ }^{(15,18)}$.

Oxygen saturation is also commonly used during exercise tests in patients with several different conditions to monitor the occurrence of hypoxaemia caused by exercise.

Most studies carried out have appraised the effect of nail polish on the pulse oximetry among healthy individuals at rest. In these cases, the small variations as described in SPO2 have no clinical significance, which could not be the case among people with pulmonary diseases when subjected to exercise.

The aim of the present study was that of appraising the interference of the colour of the nail polish on the reading of peripheral oxygen saturation $\left(\mathrm{SpO}_{2}\right)$ among patients with chronic pulmonary obstructive disease (CPOD) when taking exercise.

\section{Methods}

A quasi-experimental study was carried out, in the pneumology outpatient department of the Júlio Müller University Hospital (Hospital Universitário Júlio Müller -HUJM) in the city of Cuiabá, State of Mato Grosso, Brazil, between November 2007 and December 2008. This study was approved by the Research Ethics Committee of HUJM (protocol No. 327/CEP-HUJM/07) and also by the Research and Ethics Committee of the Federal University of São Paulo (UNIFESP), under registration No. 1794/07.

The participants in the study were adult volunteers with stable DPOC (without any signs of respiratory discomfort and without exacerbation periods in the six weeks running up to their inclusion in the study), of both genders, non-smokers or former smokers. The seriousness of the obstruction of the DPOC was based on the criteria as proposed by the GOLD consensus(21). All volunteers were duly informed about the procedures and the aims of this study, and also signed a Declaration of Free and Clarified Consent before the survey got under way.

The following classes of patients were excluded from the study: patients with heart problems (cardiac insufficiency, arrhythmia); patients with osteomuscular problems, sclerodermia and omicomicosis; patients with haemoglobin values $(\mathrm{Hb})$ either $<13.5$ or $>17,5 \mathrm{~g} / \mathrm{dL}$ for men or $\mathrm{Hb}<12$ or $>16.5 \mathrm{~g} / \mathrm{dLfor}$ women; haematocrit (Htc) $<40.5$ or $>52.0 \%$ for men or $<36$ or $>48 \%$ for women; people with total bilirubin of $<0.4$ or $>1.2 \mathrm{mg} /$ $\mathrm{dL}$ and direct and indirect bilirubin of more than $0.4 \mathrm{mg} /$ $\mathrm{dL}$; systematic arterial hypertension; altered peripheral perfusion with capillary filling of $>3$ seconds; carbon monoxide measure $(\mathrm{CO}) \geq 10 \mathrm{ppm}$ checked with the use of the monoximeter (MicroCo meter made by Micro Medical Ltd), according to the study protocol proposed by Santos et al (2001)(22).

Measures of $\mathrm{SpO}_{2}$ were taken on the fingers of both hands, at the top of the nail bed, before the collection of the data, to make sure of the homeogeneity of the measurements and also to check if there has been any difference in the $\mathrm{SpO}_{2}$ measure between the two hands. Values of $\mathrm{SpO}_{2}$ with a difference of $\pm 2 \%$ were accepted.

Four different colours of nail polish were used: base, red, light pink, and brown, all being of the Risqué ${ }^{\circledR}$ brand. The colours chosen are the most commonly used in our environment. The application of the nail polish on the right hand was made starting on the little finger, going towards the thumb. The distribution of the colours of the nail polish was random for each patient, but always following the sequence of application.

Each finger of the right hand which was subjected to the procedure had the corresponding finger on the other hand as a control. After the application of the second coat of nail polish, a spray was then used to ensure complete drying.

For the measurement of $\mathrm{SpO}_{2}$ two portable pulse oximeters of the Nonin brand were used. The equipment was tested in advance, before the measurements of $\mathrm{SpO}_{2}$, and variations of $\pm 2 \%$ in the $\mathrm{SpO}_{2}$ readings were accepted, between the two pulse oximeters(2). During the verification of measurements, the sensor remained on the finger without any variation in saturation value for 15 seconds, to reduce the margin of error before the $\mathrm{SpO}_{2}$ was registered. The time was controlled using a digital chronometer (sport timer).

After the patients were made aware of the carrying out of the exercise, these were subjected to prior training to make sure they would be able to carry out the activity. The exercise used was the step exercise ${ }^{(23)}$. The patients had to go up and down a standardised step with a height of $20 \mathrm{~cm}$, both for men and for women, according to the intensity and also the rhythm of the 
patient, for a period of six minutes. After every minute, they were encourageds to complete the exercise.

During the exercise, the patients used an affixing and immobilising device on both hands and forearms, and were also advised to avoid excess movements with their wrists and their fingers, in order to reduce as much as possible the movement of trhe sensor, to avoid possible changes to $\mathrm{SpO}_{2}$.

The $\mathrm{SpO}_{2}$ measurements before the exercise were made both before and after the application of the nail polish, with the patient being seated confortably and with hands supported. The first measure recorded was at zero time $\left(T_{0} r\right)$, which is prior to the application of the nail polish, and the second at time one ( $T_{1}$ rep), after the complete drying of the nail polish, totalling two measurements.

During exercise, the measurements were recorded at $4\left(\mathrm{~T}_{4} \mathrm{ex}\right), 5\left(\mathrm{~T}_{5} \mathrm{ex}\right)$ and $6\left(\mathrm{~T}_{6} \mathrm{ex}\right)$ minutes after the start of the exercise.

The exercise would be stopped if the patients showed $\mathrm{SpO}_{2}<80 \%$, dizziness or if they asked to stop. In case of any interruption, the test was repeated after the $\mathrm{FC}$ and also the $\mathrm{SpO}_{2}$ returned to the base levels.

The data was expressed as mean and standard deviation, or as a percentage.

The mean values of $\mathrm{SpO}_{2}$ were calculated before and after the application of the nail polish and also at the end of the exercise, for each colour of nail polish as assessed. The values observed were compared through the use of analysis of variance for repeated measurements (ANOVA-MR) with the use of the SPSS statistical software package, version 17.0 (Chicago, IL, United States).

For a comparison between different appraisal moments, there was the use of a construction of contrasts that allowed such an appraisal within the very model of ANOVA-MR, to make sure that the type I error for all comparisons was set at a fixed value of $5 \%$. All statistical tests carried out were two-tailed. A value less than 0.05 was considered significant.

\section{Results}

Initially, 51 patients with DPOC were selected. Out of this new reduced universe, nine patients were excluded: two for having low haemoglobin levels and haematocrit; four for levels of $\mathrm{SpO}_{2}$ desaturation $<80 \%$ during exercise; one who interrupted the test due to leg pain; one who interrupted the test because of dyspnea; and one who was not able to perform the CO measurement test. This means that a total of 42 patients were finally included in the study. The characteristics of the sample are shown in Table 1.

The average age of the subjects was 63 years, and there was a prevalence of males and non-whites. The seriousness of the disease was homogeneous in distribution and the time as a smoker ranged from 18 to 59 years. We also see normal values for the measurements of exhaled carbon monoxide, haemoglobin, haematocrit and bilirubin.

Table 1 - Demographic and clinical data of patients with DPOC

\begin{tabular}{|c|c|}
\hline Characteristics & $N=42$ \\
\hline Age (years)* & $62.9 \pm 8.7$ \\
\hline \multicolumn{2}{|l|}{ Sex $^{\dagger}$} \\
\hline Female & $19(45.2 \%)$ \\
\hline Male & $23(54.8 \%)$ \\
\hline Weight $(\mathrm{kg})^{*}$ & $66.7 \pm 15.1$ \\
\hline BMI $(\mathrm{Kg} / \mathrm{m} 2)^{*}$ & $26.7 \pm 5.6$ \\
\hline \multicolumn{2}{|l|}{ Ethnic Group ${ }^{\dagger}$} \\
\hline White & $17(40.5 \%)$ \\
\hline Non-White & $25(59.5 \%)$ \\
\hline \multicolumn{2}{|l|}{ Seriousness $^{\dagger}$} \\
\hline Light & $16(38.10 \%)$ \\
\hline Moderate & $10(23.81 \%)$ \\
\hline Serious & $16(38.10 \%)$ \\
\hline \multicolumn{2}{|l|}{ Oxygenotherapy $^{\dagger}$} \\
\hline No & $42(100.0 \%)$ \\
\hline Carbon Monoxide $(\mathrm{ppm})^{*}$ & $5 \pm 2$ \\
\hline Haemoglobin $(\mathrm{g} / \mathrm{dL})^{*}$ & $14.3 \pm 1.2$ \\
\hline Haematocrit $(\%)^{*}$ & $42.5 \pm 3.5$ \\
\hline Total Bilirubin $(\mathrm{mg} / \mathrm{dL})^{*}$ & $0.6 \pm 0.3$ \\
\hline \multicolumn{2}{|l|}{ Cyanosis† } \\
\hline No & $42(100.0 \%)$ \\
\hline \multicolumn{2}{|l|}{ Former Smoker ${ }^{\dagger}$} \\
\hline Yes & $38(90.5 \%)$ \\
\hline No & $4(9.5 \%)$ \\
\hline \multicolumn{2}{|l|}{ Years as a smoker } \\
\hline Mean \pm SD & $38 \pm 10$ \\
\hline Minimum and Maximum & $18-59$ \\
\hline \multicolumn{2}{|l|}{ Packs per Year } \\
\hline Median $(\mathrm{Q} 1-\mathrm{Q} 3)^{\ddagger}$ & $37(11-52)$ \\
\hline Minimum - Maximum & $5-118$ \\
\hline \multicolumn{2}{|l|}{ Age on starting to smoke } \\
\hline Mean \pm SD & $16 \pm 6$ \\
\hline Minimum - Maximum & $8-44$ \\
\hline
\end{tabular}

* Mean \pm standard deviation

+ Frequency and percentage

₹ (Q1 - Q3) First and third quartile - Interquartile Range, ppm = parts per million, $\mathrm{g} / \mathrm{dL}=$ grammes per decilitre, $\mathrm{mg} / \mathrm{dL}=$ milligrammes per decilitre

No difference was found between the saturation measurements for the right hand and for the left hand at rest, before the nail polish was applied (Table 2). 
Table 2 - Difference between the $\mathrm{SpO}_{2}$ of the fingers (right - left) at rest, before the nail polish is applied

\begin{tabular}{lcc}
\hline \multicolumn{1}{c}{ Finger } & Mean Difference* & $\mathbf{p}^{\dagger}$ \\
\hline Little Finger & -0.16 & 0.20 \\
Ring Finger & -0.11 & 0.34 \\
Middle Finger & -0.03 & 0.84 \\
Index Finger & -0.17 & 0.30 \\
Thumb & -0.09 & 0.59 \\
\hline
\end{tabular}

$* \mathrm{Z}=$ Analysis of variance $(\mathrm{F}=0.55 ; \mathrm{p}=0.70)$

tPaired t-test

In Table 3, we can see the average $\mathrm{SpO}_{2}$ with the different colours of polish and the respective controls, during the exercise periods. When the data of the right hand are compared with the respective controls over time, there was a statistically significant difference for the red and brown colours $(p<0.001)$, for which smaller values were observed. However, the significant fall in the red and brown colours was similar to that observed in the respective controls in the same measurement periods. This fact suggests that the fall in saturation that occurred during exercise was made stronger in the case of these colours.

Table 3 - Mean \pm standard deviation of $\mathrm{SpO}_{2}$ among patients with DPOC for different colours with their respective controls, over time

\begin{tabular}{|c|c|c|c|c|c|c|}
\hline & TO & T1rep & T4ex & T5ex & T6ex & p-value \\
\hline Base & $95.0 \pm 1.7$ & $94.6 \pm 2.0$ & $94.1 \pm 2.7$ & $93.7 \pm 3.0$ & $94.1 \pm 3.2$ & 0.291 \\
\hline Control & $95.0 \pm 1.9$ & $94.9 \pm 1.9$ & $94.1 \pm 2.8$ & $93.9 \pm 3.2$ & $93.7 \pm 3.2$ & 0.187 \\
\hline$p$ & 0.924 & 0.337 & 0.924 & 0.388 & 0.084 & \\
\hline Pink & $95.0 \pm 1.9$ & $94.8 \pm 2.1$ & $93.8 \pm 3.0$ & $93.9 \pm 3.1$ & $93.8 \pm 3.5$ & 0.152 \\
\hline Control & $95.0 \pm 1.9$ & $94.8 \pm 2.1$ & $94.3 \pm 2.9$ & $94.4 \pm 2.9$ & $93.9 \pm 3.4$ & 0.383 \\
\hline$p$ & 1.000 & 0.773 & 0.044 & 0.055 & 0.773 & \\
\hline Red & $95.0 \pm 1.8$ & $94.8 \pm 2.0$ & $93.5 \pm 3.3$ & $93.8 \pm 3.1$ & $93.8 \pm 3.4$ & 0.047 \\
\hline Control & $95.1 \pm 1.8$ & $95.0 \pm 2.0$ & $93.8 \pm 3.1$ & $94.1 \pm 3.3$ & $94.0 \pm 3.1$ & 0.118 \\
\hline$p$ & 0.701 & 0.924 & 0.924 & 0.924 & 0.924 & \\
\hline Marrom & $95.0 \pm 1.8$ & $93.8 \pm 2.3$ & $92.5 \pm 3.8$ & $93.4 \pm 4.0$ & $93.0 \pm 3.7$ & $<0.001$ \\
\hline Controle & $95.2 \pm 1.8$ & $94.8 \pm 1.8$ & $94.0 \pm 3.2$ & $94.1 \pm 3.2$ & $94.0 \pm 3.5$ & 0.237 \\
\hline$p$ & 0.924 & 0.502 & 0.125 & 0.250 & 0.631 & \\
\hline
\end{tabular}

T0 = Zero time, before the polish is applied; $T_{1} r=$ Time one at rest, after the polish is applied; $T_{4} e=$ Time four during exercise; $T_{5} e=$ Time five during exercise; $\mathrm{T}_{6} \mathrm{e}=$ Time six during exercise.

To establish which colours differed in each of the time points that showed a significant difference, there was an analysis made based on multiple comparisons. In Table 4 we can see that, in the comparison between the base and brown colours at the time moment $T_{1}$ rep, there was a marginally significant difference. The average saturation of the pink colour was statistically greater than that shown by brown at the time moments T1rep, T4ex e T6ex $(p=0.022, p=0.003$ and $p=0.050$, respectively), and the average saturation of red was statistically greater than that shown for brown, in the three instances of appraisal $(p<0.05)$. Thus, we can conclude that the colour brown presented an average saturation which was lelss than those observed for the other colours, at the moments T1rep, T4ex and T6ex.
Table 4 - Comparative table between the diferences of means of $\mathrm{SpO}_{2}$ between the different colours during the exercise

\begin{tabular}{lccc}
\hline & T1r & T4ex & T6ex \\
\hline Base vs Pink & $-0.2 \pm 0.3$ & $0.3 \pm 0.3$ & $0.3 \pm 0.3$ \\
& $(p=0.671)$ & $(p=0.479)$ & $(p=0.357)$ \\
Base vs Red & $-0.2 \pm 0.4$ & $0.6 \pm 0.4$ & $0.3 \pm 0.4$ \\
& $(p=0.624)$ & $(p=0.174)$ & $(p=0.514)$ \\
Base vs Brown & $0.8 \pm 0.5$ & $1.6 \pm 0.5$ & $1.1 \pm 0.5$ \\
& $(p=0.084)$ & $(p=0.002)$ & $(p=0.019)$ \\
Pink vs Red & $0.0 \pm 0.3$ & $0.3 \pm 0.3$ & $0.0 \pm 0.3$ \\
& $(p=0.832)$ & $(p=0.288)$ & $(p=0.944)$ \\
Pink vs Brown & $1.0 \pm 0.4$ & $1.3 \pm 0.4$ & $0.8 \pm 0.4$ \\
& $(p=0.022)$ & $(p=0.003)$ & $(p=0.050)$ \\
Red vs Brown & $1.0 \pm 0.3$ & $1.0 \pm 0.3$ & $0.8 \pm 0.3$ \\
& $(p=0.002)$ & $(p=0.006)$ & $(p=0.009)$ \\
\hline
\end{tabular}

$\mathrm{T} 1 \mathrm{r}=$ Time one at rest, after the nail polish is applied; $\mathrm{T} 4 \mathrm{e}=$ Time four during exercise; $\mathrm{T} 6 \mathrm{e}=$ Time six during exercise. 


\section{Discussion}

Nail polish has been described in specialised literature as one of the factors that could bring changes to $\mathrm{SpO}_{2}{ }^{(10-12)}$. However, there is controversy about the colours which could bring changes to the values of $\mathrm{SpO}_{2}$, and also if these changes could have repercussions on clinical practice to suggest the removal, or not, of the nail polish.

In a study carried out with healthy volunteers at rest, it was observed that the colours green and blue reduced $\mathrm{SpO}_{2}$ by about $6 \%$, while black and brown caused a reduction of $3 \%{ }^{(10)}$. In another similar study, the colours blue, beige, purple and white brought about significant declines in $\mathrm{SpO}_{2}{ }^{(11)}$. A third study, using ten different colours of nail polish on healthy volunteers, showed only brown and black to reduce $\mathrm{SpO}_{2}$, from $97 \pm 0.31 \%$ to $95 \pm 0.46 \%$ and $95.9 \pm 0.06 \%$ to $93.9 \pm 0.94 \%$ respectively ${ }^{(12)}$.

These differences are apparently explained by a greater difference in the absorption of light by spectrophotometry, leading the pulse oximeter to detect a greater proportion of deoxyhaemoglobin(10). In our study, the base colour, as well as light pink and red, did not have any influence on the $\mathrm{SpO}_{2}$ reading among bearers of DPOC at rest and also during exercise, while only brown brought $\mathrm{SpO}_{2}$ down ( $95 \pm 1.8 \%$ to $93.8 \pm 2.3 \%$ ), with a mean $\mathrm{SpO}_{2}$ difference of $1.2 \pm 0.5 \%$ when at rest. Our data has also confirmed the findings of other studies that have also observed a reduction in $\mathrm{SpO}_{2}$ with the use of nail polish, but without any relevance on clinical practice due to the small diferences observed ${ }^{(15,18)}$.

In patients with pulmonary disease, measurements of the oxygenation of arterial blood during exercise could be important for the appraisal of the disease, accompaniment of the response to the treatment, and also the analysis of the need for supplementing the oxygen supply, the seriousness of the illness and also the symptoms associated to exercise. Several studies have shown that the pulse oximeter supplies accurate measurements of the arterial oxygen saturation in healthy individuals during exercise and also among patients with pulmonary problems ${ }^{(24)}$.

When we assess the different colours over time, we see that the base colour and also light pink have not had any influence on the $\mathrm{SpO}_{2}$ reading. In contrast, red brought a reduction in $\mathrm{SpO}_{2}$ in the fourth minute of exercise when compared to rest, varying from $94.8 \pm 2.0 \%$ to $93.8 \pm 3.4 \%$, and brown reduced $\mathrm{SpO}_{2}$ at rest and also at the different time points during the exercise. Only one study(15) assessed the variation of $\mathrm{SpO}_{2}$ over a period of five minutes, with the $\mathrm{SpO}_{2}$ values being recorded every minute. In this study, the authors confirmed that the $\mathrm{SpO}_{2}$ values remained constant over time, but this study was conducted with healthy individuals and at rest. Among the four colours used, only red showed a significant interference on the $\mathrm{SpO}_{2}$ reading. However, the altered values were still within the limits of normality, varying between 96 and 99\%. In the present study, red showed a reduction in $\mathrm{SpO}_{2}$, but the decline was also small $(1.3 \pm 0.5 \%)$ in spite of the statistical significance. In addition, the results are different in the fact that the present study has been carried out with patients while taking exercise.

The findings of the present study are in agreement with a study carried out on healthy individuals subjected to conditions of hypoxia induced by high altitudes, at rest and also while taking exercise (walking), which did not affect the $\mathrm{SpO}_{2}$ readings when different colours of nail polish were used, including brown, red and pink ${ }^{(25)}$.

In our study, the reduction in the $\mathrm{SpO}_{2}$ values during exercise was significant in the case of brown, when compared to the other colours - namely base colour, light pink and red, both at the fourth and the sixth minute of exercise, showing a lower value for $\mathrm{SpO}_{2}$ with statistical significance. The differences between the means ranged between $0.8 \pm 0.3 \%$ and $1,6 \pm 0.5 \%$ during exercise.

Important limitations in all studies here described, which make it more difficult to compare these studies, lie in the reduced size of the sample studied, as well as the limited use of the number and the type of the different colours and also the different equipment of pulse oximetry as used. At the same time, most studies were carried out on healthy volunteers.

In addition, there were no studies found that assessed the influence of nail polish on the $\mathrm{SpO}_{2}$ value for patients with chronic obstructive pulmonary disease, during exercise. As a result, this fact makes it more difficult to compare the studies and also limits the scope of the findings to other populations and other exercise situations.

Even though in the present study a representative number of patients has been included, there has not been inclusion of any patients with significant desaturation; as also the number of colours of nail polish appraised was necessarily limited, which does not allow the present findings to be extended to other colours such as green, blue and black, as used in other similar studies.

In addition, the patients performed the step exercise for six minutes, as according to their own 
rhythm and intensity, meaning that the maximum effort may not have been reached.

\section{Conclusion}

Among patients with DPOC, the use of brown nail polish brings a reduction in the $\mathrm{SpO}_{2}$ reading, both at rest and also during exercise. The red colour only reduces $\mathrm{SpO}_{2}$ during exercise. The clinical relevance of such findings is questionable, due to the small differences that have been found.

\section{References}

1. Whar JA, Tremper KK, Diab M. Pulse oximetry. Respir Care Clin North Am. 1995;1(1):77-105.

2. Jensen LA, Onyskiw JE, Prasad NGN. Meta-analysis of arterial oxygen saturation monitoring by pulse oximetry in adults. Heart Lung. 1998;27(6):387-408.

3. McMorrouw RCN, Mythen MG. Pulse oximetry. Curr Opin Crit Care. 2006;12(3):269-71.

4. Taylor MB, Whitwan JG. The current status of pulse oximetry. Clinical value of continuous noninvasive oxygen saturation monitoring. Anaesthesia. 1986;41(9):943-9. 5. Webb RK, Ralston AC, Runciman WB. Potential errors in pulse oximetry. Part III. Effects of interference, dyes, dyshaemoglobins and others pigments. Anaesthesia. 1991;46(3):291-5.

6. Bothma PA, Joynt GM, Lipman J, Hon H, Mathala B, Scribante J, Kromberg J. Accuracy of pulse oximetry in pigmented patients. S Afr Med J. 1996;86(5):594-6.

7. Trivedi NS, Ghouri AF, Shah NK, Lai E, Baker SJ. Effects of motion, ambient light and hypoperfusion on pulse oximeter function. J Clin Anesth. 1997;9(3):17983.

8. Vegfors M, Lennmarken C. Carboxyhaemogloninaemia and pulse oximetry. Brit J Anaesth. 1991; 66(5):625626.

9. Barker SJ, Tremper KK, Hyatt J. Effects of methemoglobinemia on pulse oximetry and mixed venous oximetry. Anesthesiology. 1989;70(1):112-7.

10. Coté CJ, Goldstein A, Fuchsman WH, Hoaglin DC. The effect of nail polish on pulse oximetry. Anesth Analg. 1988;67(7):683-6.

11. Chan MM, Chan MM, Chan ED. What is the effect of fingernail polish on pulse oximetry? Chest. 2003;123(6): 2163-4.

12. Sütçü $\mathrm{CH}$, Gümüs $\mathrm{S}$, Deniz $\mathrm{O}$, Yildiz $\mathrm{S}$, Açikel $\mathrm{CH}$, Cakir $\mathrm{E}$, et al. Effect of nail polish and henna on oxygen saturation determined by pulse oximetry in healthy young adult female. Emerg Med J. 2011;28(9):783-5.
13. Kataria BK, Lampkins R. Nail polish does not affect pulse oximeter saturation. Anesth Analg. 1986;65(7):819-27.

14. Brand TM, Brand ME, Jay GD. Enamel nail polish does not interfere with pulse oximetry among normoxic volunteers. J Clin Monitor Comput. 2002;17(2):93-6. 15. Miyake $M H$, Diccini $S$, Bettencourt ARC. Interferência da coloração de esmaltes de unha e do tempo na oximetria de pulso em voluntários sadios. J Bras Pneumol. 2003;29(6):386-90.

16. Coté CJ, Goldstein A, Fuchsman WH, Hoaglin DC. The effect of nail polish on pulse oximetry. Anesth Analg. 1988;67(7):683-6.

17. Chan MM, Chan MM, Chan ED. What is the effect of fingernail polish on pulse oximetry? Chest. 2003;123(6):2163-4.

18. Rodden AM, Spicer L, Diaz VA, Steyer TE. Does fingernail polish affect pulse oximeter readings? Intens Crit Care Nurs. 1990;23(1):51-5.

19. Rubin AS. Nail polish color can affect pulse oximeter saturarion. Anesthesiology. 1988;68(5):825.

20. Hinkelbein J, Genzwuerker HV, Sogl R, Fiedler F. Effect of nail polish on oxygen saturation determined by pulse oximetry in critically ill patients. Resuscitation. 2007;72(1):82-91.

21. Global Initiative for Chronic Obstructive Lung Disease. Global strategy for the diagnosis, management, and prevention of chronic obstructive pulmonary disease (updated 2010) [acesso 15 dez 2011]; Disponível em: http://www.gold-copd.org/uploads/users/files/ GOLDReport_April112011.pdf.

22. Santos UP, Gannam S, Abe JM, Esteves PB, Freitas M Filho, Wakassa TB, Issa JS, et al. Emprego da determinação do monóxido de carbono no ar exalado para detecção do uso de tabaco. J Bras Pnemol. 2001;27(5):231-6.

23. Dal Corso S, Duarte SR, Neder JA, Malaguti C, Fuccio MB, Pereira CAC, Nery LE. A step test to assess exerciserelated oxygen desaturation in interstitial lung disease. Eur Respir J. 2007;29(2):330-6.

24. Escorrou PJL, Delaperche MF, Visseaux A. Reliability of pulse oximetry during exercise in pulmonary patients. Chest. 1990;97(3):635-8.

25. Yamanoto LG, Yamanoto JA, Yamanoto JB, Yamanoto $B E$, Yamanoto PP. Nail polish does not significantly affect pulse oximetry mesuraments in mildly hipoxic subjects. Respir Care. 2008;53(11):1470-4.

Received: June $19^{\text {th }} 2012$ Accepted: Oct. $17^{\text {th }} 2012$ 